\title{
Development of bioanode for versatile applications: microfuel cell system in the presence of alcohol and glucose
}

\author{
J. Ledesma-García ${ }^{1}$ - M. P. Gurrola ${ }^{3,4}$ - D. L. Trejo-Arroyo ${ }^{3,4}$ - J. A. Rodríguez-Morales ${ }^{1}$ - A. Gutiérrez ${ }^{5}$. \\ R. A. Escalona-Villalpando ${ }^{1}$ · L. G. Arriaga ${ }^{2}$
}

Received: 18 October 2021 / Accepted: 2 February 2022 / Published online: 22 February 2022

(c) The Author(s) 2022

\begin{abstract}
The purpose of this work is to develop a bioanode using the enzymes of glucose oxidase (GOx) and alcohol dehydrogenase $(\mathrm{ADH})$ as catalysts to oxidised glucose and alcohol present in different beverages. The study was carried out using the covalent bonding method for both enzymes via the functionalization of carbon nanofibers for the formation of carboxyl groups that can form bonds with the amine groups of the enzyme, as well as using tetrabutylammonium bromide (TBAB) with Nafion. The optimum operation parameters of both enzymes ( $\mathrm{pH}$ and temperature) were determined for the later evaluation in a microfluidic fuel cell. In addition, using the scanning electrochemical microscopy technique, a local study of enzymatic processes is used to demonstrate that the enzymes immobilized on the same electrode remain active. The evaluation of the microfluidic fuel cell was carried out using different solutions, $0.01 \mathrm{M}$ glucose, $0.01 \mathrm{M}$ ethanol and a mixture of $0.01 \mathrm{M}$ glucose and $0.01 \mathrm{M}$ ethanol, all in phosphate buffer solutions at $\mathrm{pH} 7$, where it was possible to obtain a maximum performance of $5.07 \pm 0.1 \mathrm{~mW} \mathrm{~cm}{ }^{-2}$, and there was a significant increase in current density compared to non-composite solutions (glucose or ethanol). In addition, different alcoholic beverages were used to evaluate the versatility and adaptability of the bi-enzymatic anode electrode with the perspective use in Lab-on-a-Chip systems.
\end{abstract}

Keywords Bioelectrodes $\cdot$ Microfuel cell $\cdot$ Glucose oxidation $\cdot$ Ethanol oxidation $\cdot$ Microdevice

J. Ledesma-García

janet.ledesma@uaq.mx

1 Facultad de Ingeniería, División de Investigación y Posgrado, Universidad Autónoma de Querétaro, Centro Universitario Cerro de Las Campanas, 76010 Querétaro, Qro, Mexico

2 Centro de Investigación y Desarrollo Tecnológico en Electroquímica, 76703 Pedro Escobedo, Qro, Mexico

3 Tecnológico Nacional de México/Instituto Tecnológico de Chetumal, Av. Insurgentes 330, David Gustavo Gutiérrez, 77013 Chetumal, Quintana Roo, Mexico

4 Cátedra Consejo Nacional de Ciencia y Tecnología-Tecnológico Nacional de México/Instituto Tecnológico de Chetumal, David Gustavo Gutiérrez, Av. Insurgentes 330, 77013 Chetumal, Quintana Roo, Mexico

5 Tecnológico de Estudios Superiores de Huixquilucan, Paraje El Río S/N, La Magdalena Chichicaspa, 52773 Huixquilucan, Edo. de México, Mexico

\section{Introduction}

Multi-enzymatic processes are becoming increasingly attractive for the oxidation of a wide range of complex organic fuels, due to their possible applications [1]. Oxidation with multi-enzymatic bioanodes improves the amount of energy derived per unit of mass substrate, reducing the amount of fuel consumed and possibly increasing the current density, in addition to generating electricity from two or more types of fuel in a mixed solution [2]. In this sense, the development of multi-enzymatic bioanodes continues to be an important research topic, due to enzyme diversity and the wide range of fuels that can be used (such as alcohols and sugars). Even, these systems can be employed in microfluidic fuel cell prototypes for biomedical applications [3-6], with enzymes such glucose oxidase (GOx) and alcohol dehydrogenase (ADH) enzymes immobilized on the same bioanode.

Specifically, microfluidic fuel cells that use enzymes on the electrodes are bio-electrochemical systems that generate electrical current from a variety of organic liquid fuels and oxidants under laminar flow regimen with a low Reynolds 
number and a high Peclet number [7-10], and their potential uses have attracted the attention driven to energy conversion, where reactions are catalysed by redox enzymes; however, still have the challenge of generating clean energy [11-13]. Secondly, enzymes are biocompatible and biodegradable catalysts, operating under mild conditions in water, with high rates and selectivity [14]. For energy applications, the catalytic activity of an enzyme immobilized on the electrode surface is an important factor for achieving a high power output of the device [15]. The creation of electrodes modified with enzymes, which depend on the enzymatic immobilization and the conservation of their activity, used for the bioelectrocatalytic process in microfluidic fuel cells is an important challenge to overcome [16-22].

The most used enzyme in fuel cells is glucose oxidase (GOx), which oxidizes glucose into gluconolactone at the anode [23]. A wide variety of materials have been used for the immobilization of this enzyme such as carbon nanotubes [24-26], graphene [27], polymers [24, 25], metallic nanoparticles [27, 28], etc. However, there are two important limitations of GOx immobilized on solid electrodes: poor electrical communication between the GOx active site and electrode surface, and enzyme leaching [29]. The preparation of suitable electrode array is very important for overcoming these issues. However, the electrode array should not alter the mechanical stability and catalytic capacity of Gox [30].

Nevertheless, the alcohol dehydrogenase enzyme (ADH) is an oxidoreductase that catalyses the reversible oxidation of alcohols to their corresponding carbonyl compounds [31] using nicotinamide adenine dinucleotide $\left(\mathrm{NAD}^{+}\right)$as a coenzyme. The reduced form of this coenzyme, NADH + $\mathrm{H}^{+}$, generated in the enzymatic reaction is oxidized back to $\mathrm{NAD}^{+}$on the electrode surface at a suitable potential [32, 33].

The critical point in the design of electrodes based on a co-immobilization of these two enzymes is to achieve that they can perform the oxidation of their corresponding fuel when they are on the same electrode since each enzyme has a different chemical composition. Finding suitable immobilization methods, where there is a possibility of electronic transfer between the redox groups of the mediator and the electrode, is a key factor for the efficient development of bioelectrodes for microfluidic fuel cells to increase the power density and stability of microfluidic devices using enzymatic electrodes. Therefore, a bioelectrode based on GOx-ADH enzymes was developed in this research, using functionalized carbon nanofibres, tretrabutylammonium bromide and Nafion, applied in a microfluidic fuel cell using different fuels containing glucose and/or ethanol (red wine, rosé wine, white wine, etc.). Using different characterizations, it was possible to demonstrate that enzymes remain active when they are immobilized together, finding the optimum parameters of $\mathrm{pH}$ and temperature for each enzyme. Using the scanning electrochemical microscopy technique, it was possible to obtain images of the bioelectrode topography and show increases in the current density when the corresponding substrate was used for each enzyme. The results show the versatility of the electrode to be able to use different fuels composed of ethanol and glucose, obtaining good performance.

\section{Experimental}

\section{Reagents}

Alcohol dehydrogenase (EC 1.1.1.1 initial activity $\geq 300$ $\mathrm{U} \mathrm{mg}^{-1}$ protein from Saccharomyces cerevisiae), glucose oxidase (EC 1.1.3.4 Type X-S, lyophilized powder, 100,000-250,000 units/g solid from Aspergillus niger), tetrabutylammonium bromide (TBAB), carbon nanofibres (CNFs) potassium phosphate dibasic dihydrate $\left(\mathrm{K}_{2} \mathrm{HPO}_{4}\right)$, $\beta$-nicotinamide adenine dinucleotide sodium salt $\left(\mathrm{NAD}^{+}\right)$, potassium phosphate monobasic monohydrate $\left(\mathrm{KH}_{2} \mathrm{PO}_{4}\right)$, Nafion ${ }^{\circledR}$ (5\% diluted in water), and potassium hydroxide (88.7\%) were purchased from Sigma-Aldrich.

\section{Functionalization of carbon nanofibers (CNFs)}

CNFs were treated with $\mathrm{HNO}_{3} / \mathrm{H}_{2} \mathrm{SO}_{4}(1: 3)$ for $3 \mathrm{~h}$ at $40{ }^{\circ} \mathrm{C}$ in a water bath sonicator. Then, the mixture was centrifuged, and the precipitate was washed with deionized water to $\mathrm{pH}$ 7.0 and dried at $90{ }^{\circ} \mathrm{C}$ for $8 \mathrm{~h}$ to obtain carboxylic group functionalization [34].

\section{Bioanode preparation}

Three different bioanodes were constructed for the measurements, one with glucose oxidase as biocatalyst, another with alcohol dehydrogenase and the third with a co-immobilization of both enzymes. For GOx and ADH bioanodes, inks with the following components were prepared: $1 \mathrm{mg}$ of enzyme, $1 \mathrm{mg}$ of functionalized CNFs, $10 \mu \mathrm{L}$ of Nafion, 500 $\mu \mathrm{L}$ of buffer phosphate $\mathrm{pH}=7$, and $10 \mathrm{mg}$ of TBAB. The ink for the bioanode using GOx-ADH co-immobilization was prepared using $0.5 \mathrm{mg}$ of glucose oxidase, $0.5 \mathrm{mg}$ of alcohol dehydrogenase, $1 \mathrm{mg}$ of functionalized CNFs, $10 \mu \mathrm{L}$ of Nafion, $500 \mu \mathrm{L}$ of buffer phosphate $\mathrm{pH}=7$, and $10 \mathrm{mg}$ of TBAB. All inks were sonicated for $20 \mathrm{~min}$ and mixed using a vortex for $15 \mathrm{~min}$. Each ink was deposited by immersion for $12 \mathrm{~h}$ onto Toray carbon paper (EC-TP1-060T), whose dimensions were $3 \times 10 \mathrm{~mm}$, for electrochemical and test evaluation. The GOx-ADH bioanode was physicochemically characterized via SEM using a JEOL JSM-7401F field emission scanning electron microscope. 


\section{Cathode preparation}

The abiotic cathode Pt/C for microfuel cell was prepared using commercial Pt/C (30\% E-TEK) supported on Toray carbon paper; $120 \mu \mathrm{L}$ of isopropyl alcohol and $14 \mu \mathrm{L}$ of Nafion were added per $\mathrm{mg}$ of $\mathrm{Pt} / \mathrm{C}$, mixed for $30 \mathrm{~min}$ and incorporated directly over the electrode surface via homogeneous deposition using an airbrush.

\section{Spectrophotometric determination of activity: alcohol dehydrogenase}

The determination of activity of the immobilized ADH enzyme followed a method used by Enzymatic Assay of Alcohol Dehydrogenase EC 1.1.1.1 of Sigma-Aldrich. The evaluation of two types of electrodes by triplicate, one containing ADH and other ADH-GOx immobilized on Toray carbon paper to determine the effect of the activity when the enzyme is immobilized individually and together with the enzyme glucose oxidase. A solution of enzyme diluent (10 mM sodium phosphate buffer, $\mathrm{pH} 7.5$ with $0.1 \%$ (w/v) bovine serum albumin) was prepared using a $1 \mathrm{mg} / \mathrm{mL}$ solution of bovine serum albumin in a $10 \mathrm{mM}$ sodium phosphate buffer, $\mathrm{pH}$ 7.5. Two types of reaction mixtures were prepared: a blank reaction mixture $(1.3 \mathrm{~mL}$ of a $0.1 \mathrm{M}$ phosphate buffer $\mathrm{pH}=8.86,1.5 \mathrm{~mL}$ of $15 \mathrm{mM} \mathrm{NAD}^{+}, 0.1 \mathrm{~mL}$ of $95 \%(\mathrm{v} / \mathrm{v})$ ethanol, and $0.1 \mathrm{~mL}$ of enzyme diluent) and a test reaction mixture $(1.3 \mathrm{~mL}$ of a $0.1 \mathrm{M}$ phosphate buffer $\mathrm{pH}=8.86,1.5 \mathrm{~mL}$ of $15 \mathrm{mM} \mathrm{NAD}^{+}$, and $0.1 \mathrm{~mL}$ of $95 \%$ ethanol, where the electrode was placed with a dimension of $1 \times 1 \mathrm{~cm}$ ) and was recorded at $340 \mathrm{~nm}$. The millimolar extinction coefficient of $\beta-\mathrm{NADH}$ at $340 \mathrm{~nm}$ is 6.22 . The average of the experiments is reported with its respective standard deviation value.

\section{Spectrophotometric determination of activity of glucose oxidase enzyme}

The GOx activity for the two types of electrodes, one containing GOx and another containing ADH-GOx immobilized on Toray carbon paper, was determined by quantifying the amount of hydrogen peroxide produced using 3,30,5,50-tetramethylbenzidine (TMB) as a co-substrate.

Glucose oxidase $+\mathrm{H}_{2} \mathrm{O} \stackrel{\text { Glucose oxidase }}{\longrightarrow}$ Gluconic acid $+\mathrm{H}_{2} \mathrm{O}_{2}$

$\mathrm{H}_{2} \mathrm{O}_{2}+\mathrm{TMB} \stackrel{\text { Horseradish peroxidase }}{\longrightarrow}$ Oxidized TMB

The determination of GOx activity is performed in two steps. In the first step, glucose is oxidized by dissolved oxygen in the presence of GOx to produce $\mathrm{H}_{2} \mathrm{O}_{2}$, while in the second step, this $\mathrm{H}_{2} \mathrm{O}_{2}$ oxidizes TMB by horseradish peroxidase. A solution was prepared containing $5 \mathrm{mM}$ D-glucose, $30 \mu \mathrm{L}$ of TMB, and $1.4 \mathrm{~mL}$ of a peroxidase solution ( $4.3 \mathrm{mg} \mathrm{mL}^{-1}$ ) in a $0.1 \mathrm{M}$ phosphate buffer $\mathrm{pH} 7.0$, where the electrode $(1 \times 1 \mathrm{~cm})$ was incubated, and absorbance was measured at $450 \mathrm{~nm}$ [35]. Peroxidase has a significant potential for practical application and can be used as a diagnostic kit for hydrogen peroxide $\left(\mathrm{H}_{2} \mathrm{O}_{2}\right)$ and glucose [36]. For estimating the enzymatic activity, the molar extinction coefficient for TMB of $5.9 \times 10^{4} \mathrm{M}^{-1} \mathrm{~cm}^{-1}$ was used, where one unit of glucose oxidase activity (U) was defined as the amount of enzyme required to catalyse the oxidation of $1 \mathrm{~mol}$ of a-D-glucose per minute $\left(\mathrm{pH} 7.0,25^{\circ} \mathrm{C}\right)$.

\section{Electrochemical characterization}

Electrochemical characterization was performed by cyclic voltammetry using a BioLogic VSP Potentiostat/Galvanostat and a three-electrode electrochemical cell. Toray slides (ETEK) dimensions modified with biocatalysts were used as working electrodes; the $\mathrm{Ag} / \mathrm{AgCl}$ sat. $\mathrm{KCl}$ as reference and, a graphite rod as the counter electrode. Phosphate buffer solutions were deaerated with nitrogen gas (Infra 5.0 UAP).

The enzymatic activity of GOx and ADH immobilized in the bi-enzymatic anode was investigated via scanning electrochemical microscopy (SECM) using a Biologic scanning system instrument model ac-SECM/SECM470, employing a four electrode cell consisting of a platinum ultramicroelectrode (UME) of $25 \mu \mathrm{m}$ diameter, a reference electrode of $\mathrm{Ag}|\mathrm{AgCl}| 3 \mathrm{M} \mathrm{KCl}$, with a graphite rod as an auxiliary electrode and a developed bioanode electrode that was attached to a graphite electrode using a conductive carbon tape. The SECM tip was positioned next to bioelectrode in the electrochemical cell by means of visual control. Subsequently, a z-approach curve was performed in a $5 \mathrm{mM}$ solution of $\mathrm{K}_{3}\left[\mathrm{Fe}(\mathrm{CN})_{6}\right]$ in $0.1 \mathrm{M}$ phosphate buffer at $150 \mathrm{mV}$ of constant potential. A potential surface tilt between sample and scanning plane was compensated using a software tool which is determining a plane parallel to the sample surface by means of three consecutive z-approach curves. The z-position of the SECM tip is then adjusted during scanning in that way that the scanning plane remains parallel to the determined plane of the sample surface.

\section{Schematic representation of the microfluidic fuel cell architecture (mFFC)}

Microfuel cell was constructed using poly-(methyl methacrylate) (PMMA) for the fuel and oxidant channels; the cathode electrode was incorporated as a wall to obtain the major $\mathrm{O}_{2}$ quantity for the reduction reaction. The bioanode was in a transverse position to the fluid flow direction. The external contact was performed using a pogo

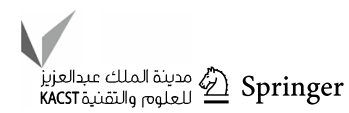


pin, the sealing layers were made of a silicone elastomer film (Silastic ${ }^{\circledR}$ ) and cut using the cutter plotter (Grapthec America Inc.). The fuels used were glucose, ethanol, and a glucose-ethanol mix solution at different concentrations using an electrolyte support of buffer phosphate at different $\mathrm{pH}$ values. The performance of the microfluidic fuel cell was tested using $\mathrm{O}_{2}$-saturated $0.3 \mathrm{M} \mathrm{KOH}$ in the cathodic compartment. The schematic representation of the mFCC and the bi-enzymatic bioanode is shown in Fig. 1. In addition, the evaluation of mFFC was also performed using different alcoholic beverages (brandy, tequila, whisky and vodka). The geometric area was $0.014 \mathrm{~cm}^{2}$ and was maintained for all anodic arrays tested herein. The flow rate was $60 \mu \mathrm{L} \mathrm{min}{ }^{-1}$ for both streams. All experiments were performed by triplicate and the average \pm standard deviation value is reported.

\section{Results and discussion}

Scanning electron microscopy (SEM) was used to perform a superficial evaluation of the bare Toray paper (Fig. S1a in Supplementary information), functionalized carbon nanofibers deposited onto the surface of Toray carbon paper (Fig. $\mathrm{S} 1 \mathrm{~b})$ and the bi-enzymatic electrode, where the catalytic ink of GOx, ADH, TBAB and Nafion was deposited on the tubular structure of the electrode formed by the functionalized carbon nanofibers on Toray carbon paper (Fig. S1c). Is reported that enzymatic immobilization on porous support followed by its fixation on the porous wall, where the diffusion rate of the enzyme is slower than the immobilization rate, obtaining a greater retention of the proteins [37]. It is known that enzymatic immobilization on porous support implies the incorporation of the enzyme on the support pores followed by its fixation on the porous wall.
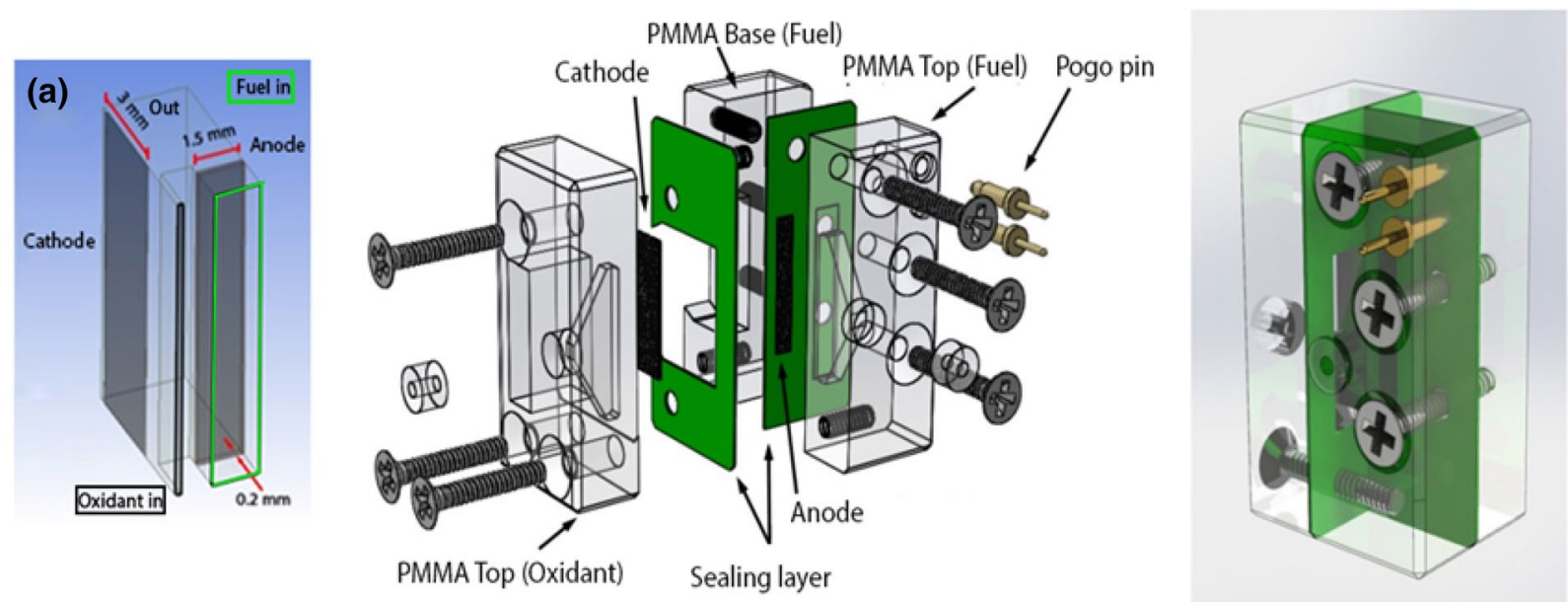

(b)

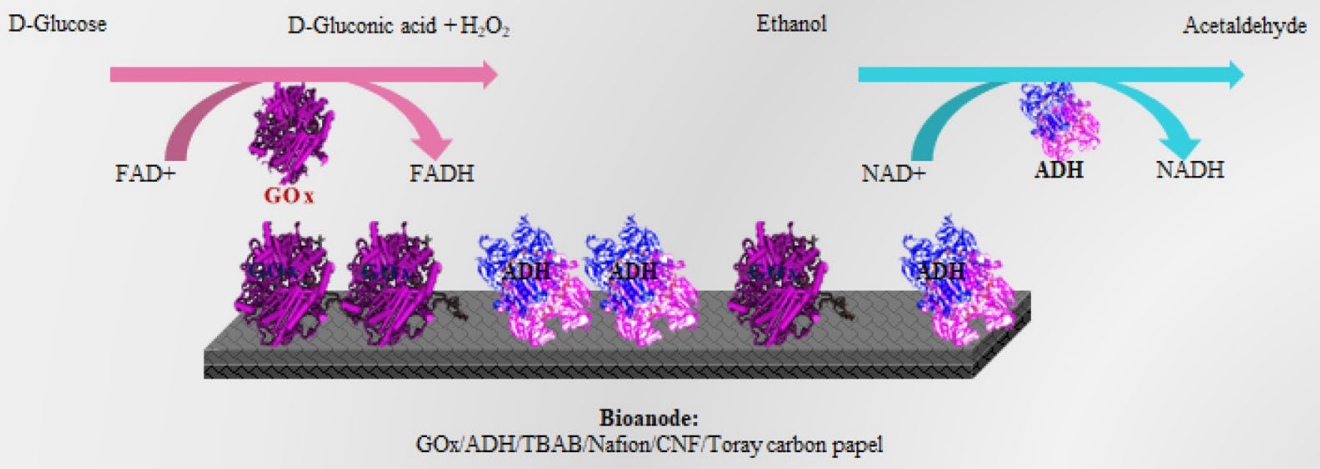

Fig. 1 a Scheme of the microfluidic fuel cell and components, using a $\mathrm{Pt} / \mathrm{C}$ cathode, bi-enzymatic bioanode array composed of Toray paper as electrode with functionalized carbon nanofibers, TBAB, Nafion, glucose oxidase and alcohol dehydrogenase enzymes. b Schematic representation of the prepared bioanode 


\section{Electrochemical characterization}

The cyclic voltammetry technique was used to identify the oxidation and reduction peaks of the bi-enzymatic bioanode corresponding to the cofactors of the enzymes, flavin adenine dinucleotide $\left(\mathrm{FAD}^{+}\right)$for glucose oxidase and nicotinamide adenine dinucleotide $\left(\mathrm{NAD}^{+}\right)$corresponding to the enzyme alcohol dehydrogenase (Fig. 2). The experiment was performed using the electrode with three different solutions: $0.01 \mathrm{M}$ glucose in $0.1 \mathrm{M}$ phosphate buffer solution, $0.01 \mathrm{M}$ ethanol in $0.1 \mathrm{M}$ phosphate buffer and a mixture of fuels $(0.01 \mathrm{M}$ glucose $+0.01 \mathrm{M}$ ethanol in the same phosphate buffer solution). All solutions were at $\mathrm{pH} 7$. As shown in Fig. 2, whereas when the glucose fuel is present, the redox peaks of $\mathrm{FAD}^{+}$and FADH appear at -0.48 and $-0.55 \mathrm{~V}$, respectively, vs. $\mathrm{Ag} / \mathrm{AgCl}$. However, the redox pair corresponding to $\mathrm{NAD}^{+}$and NADH located at -0.28 and $-0.34 \mathrm{~V}$, respectively, vs. $\mathrm{Ag} / \mathrm{AgCl}$ appear in the case of ethanol. When using a mixture of fuels, the oxidation and reduction of the two cofactors, corresponding to the two enzymes can be observed, which indicates that the bi-enzymatic bioanode can oxidize these two fuels. The glucose oxidation reaction shown in Fig. 3a at different glucose concentration was verified by differential pulse voltammetry (DPV) at -0.1 to $0.4 \mathrm{~V}$ vs $\mathrm{Ag} / \mathrm{AgCl},(240 \mathrm{~s}$ of stabilization time). Oxidation peaks located between the -0.6 and $-0.5 \mathrm{~V}$ vs Ag $/ \mathrm{AgCl}$ can be observed. Inset in Fig. $3 \mathrm{~b}$ shows the change of current density as a function of glucose concentration.

\section{Evaluation of enzymatic activity of GOx and ADH}

Enzymatic activity was carried out to evaluate three types of electrodes, two of which with GOx and ADH enzymes

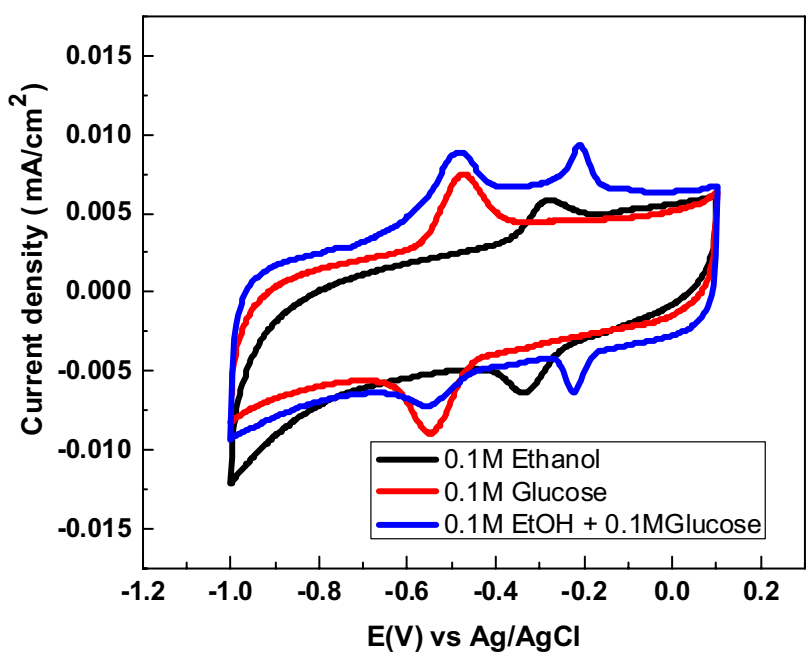

Fig. 2 Cyclic voltammograms of the redox $\mathrm{FAD}^{+}$and $\mathrm{NAD}^{+}$of bienzymatic bioanode, in the presence of $0.01 \mathrm{M}$ ethanol and $0.01 \mathrm{M}$ glucose in $0.1 \mathrm{M}$ phosphate buffer $\mathrm{pH} 7$

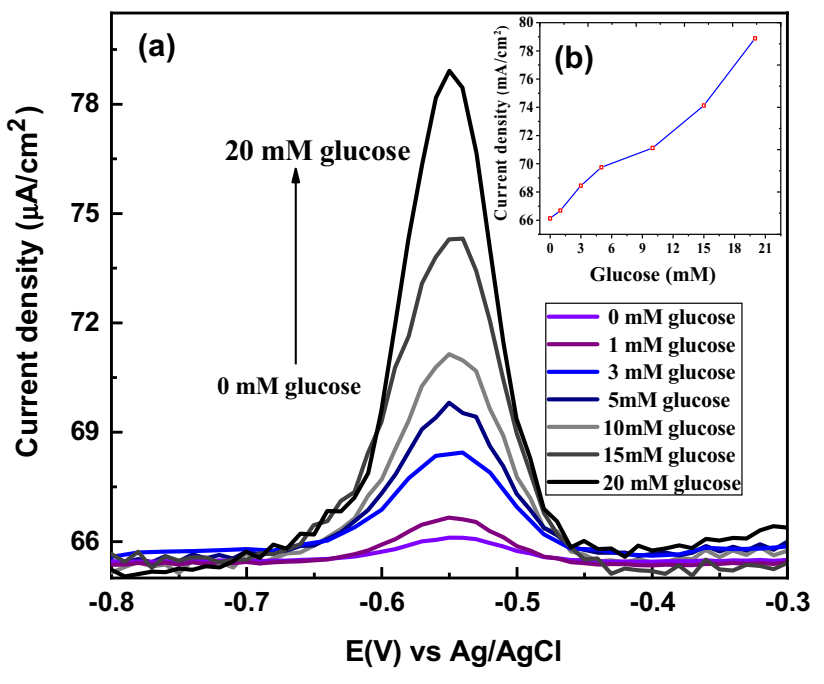

Fig. 3 a Differential pulse voltammograms of bi-enzymatic electrode in phosphate buffer solution $\mathrm{pH} 7$, at different glucose concentration; $20 \mathrm{mV} \mathrm{s}^{-1}$ scan rate; $100 \mathrm{mV}$ of amplitude and $2000 \mathrm{~ms}$ of press width. b Current density as function of glucose concentration

immobilized separately, and the third electrode consisted in bi-enzymatic bioanode (GOx-ADH). Both enzymes were immobilized using the same method.

Figure $4 \mathrm{a}$ shows the evaluation of the effect of $\mathrm{pH}$ on the activity of GOx immobilized separately and together with the enzyme ADH. For both cases, the optimum $\mathrm{pH}$ of the enzyme was in the range of 6-7, and at the $\mathrm{pH}$ basic solution, it showed a loss of residual activity of more than $50 \%$ at $\mathrm{pH}$ 9. At $\mathrm{pH}$ 6.5, GOx immobilized on the bi-enzymatic electrode showed a decrease in activity compared with when it is immobilized alone. The $\mathrm{pH}$ of glucose oxidase in a free state is 5.5 (Sigma-Aldrich), and when it is immobilized using the proposed method, the $\mathrm{pH}$ changes to 6.5 [38].

The effect of $\mathrm{pH}$ was evaluated for the activity of immobilized enzyme alcohol dehydrogenase (Fig. 4b). The optimum $\mathrm{pH}$ for the two electrodes (ADH immobilized separately and in conjunction with the glucose oxidase enzyme) was between 8 and 9.5, with a maximum residual activity at 9 , whose value is similar to that previously reported for the enzyme in the free state at 8.86 [39]. These characterizations served to establish that the enzyme glucose oxidase immobilized by the proposed method has a maximum activity at neutral $\mathrm{pH}$, whereas the enzyme alcohol dehydrogenase at alkaline $\mathrm{pH}$ presents an approximately $75 \%$ of residual activity for ADH. The enzyme immobilised on the electrode exhibited an activity of $132 \mathrm{U} / \mathrm{cm}^{2}$ of glucose oxidase corresponding to $100 \%$ residual activity. For the case of the alcohol dehydrogenase enzyme, $100 \%$ residual activity corresponds to $257 \mathrm{U} / \mathrm{cm}^{2}$.

The evaluation of the effect of temperature on the activity of the GOx and ADH enzymes immobilized separately and

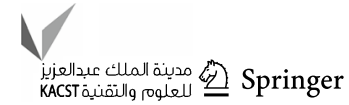



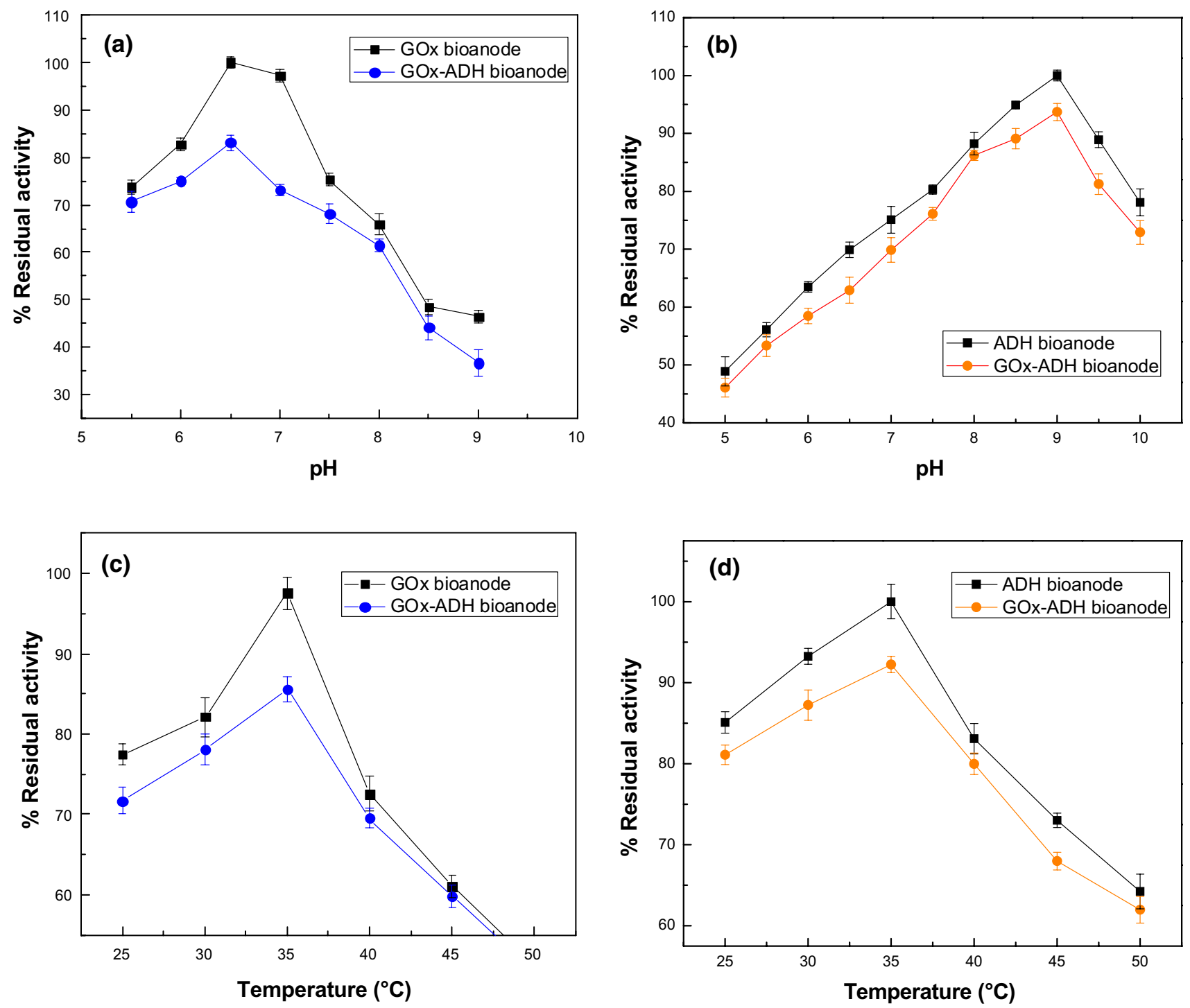

Fig. 4 Evaluation of the effect of $\mathrm{pH}$ on the activity of a glucose oxidase enzyme and $\mathbf{b}$ alcohol dehydrogenase immobilized separately and together. Evaluation of the effect of temperature on $\mathbf{c}$ glucose oxidase enzyme and $\mathbf{d}$ alcohol dehydrogenase immobilized separately and together

together (Fig. 4c, d) from 25 to $50{ }^{\circ} \mathrm{C}$ was also carried out. It was observed that the electrodes can operate at a temperature from 25 to $35^{\circ} \mathrm{C}$, which showed a positive application in a microfluidic cell that operated at room temperature with a low catalytic activity loss of both enzymes. There is a small decrease in activity when both enzymes are immobilized on the same electrode compared to when they are immobilized separately [40].

\section{Topography and localized enzymatic activity of bioanode GOx-ADH}

Scanning electrochemical microscopy (SECM) was utilized to study the activity of immobilized enzymes. It is a powerful tool that enables mapping of local chemical re-activities at interfaces and extraction of local kinetic data of heterogeneous reactions (mediated between redox enzymes and the supporting electrode surface), or detection of reaction products at the supporting electrode [41, 42]. Therefore, using this technique, the evaluation of activity of GOx and $\mathrm{ADH}$ enzymes immobilized on the same electrode was carried out at the temperature of $25^{\circ} \mathrm{C}$ in a clean room to locate where the enzymatic reactions occur on the surface of the electrode. An ultramicroelectrode tip-to-sample distance of $53 \mu \mathrm{m}$ was adjusted, which was obtained via the approach of curve recording in a $5 \mathrm{mM}$ solution of $\mathrm{K}_{3}\left[\mathrm{Fe}(\mathrm{CN})_{6}\right]$ in a $0.1 \mathrm{M}$ phosphate buffer at a potential of $-150 \mathrm{mV}$ [43]. The SECM tip was positioned next to bioelectrode in the electrochemical cell by means of visual control. Subsequently, a z-approach 
curve was performed in a $5 \mathrm{mM}$ solution of $\mathrm{K}_{3}\left[\mathrm{Fe}(\mathrm{CN})_{6}\right]$ in $0.1 \mathrm{M}$ phosphate buffer at $150 \mathrm{mV}$ of constant potential (Fig. S2). A potential surface tilt between sample and scanning plane was compensated using a software tool which is determining a plane parallel to the sample surface by means of three consecutive $\mathrm{z}$-approach curves. The z-position of the SECM tip is then adjusted during scanning in that way that the scanning plane remains parallel to the determined plane of the sample surface. Through SECM generation collection mode (GC-SECM), the ultra-micro-electrode (UME) only registers currents using the reaction products generated at the surface electrode. In the case of the enzymatic reaction of glucose oxidase, gluconolactone and hydrogen peroxide are produced. Measurements were performed by registering the $\mathrm{H}_{2} \mathrm{O}_{2}$ oxidation current by applying a potential of $700 \mathrm{mV}$ in UME, which ensures diffusion-controlled oxidation of $\mathrm{H}_{2} \mathrm{O}_{2}$ [44]. Figure 5a shows the image obtained from the measurement of glucose oxidase activity in the absence (left) and presence (right) of $10 \mathrm{mM}$ of glucose in a buffer solution of phosphates $\mathrm{pH} 7$ by analysing a surface of $400 \times 400 \mu \mathrm{m}$ of the bi-enzymatic bioanode. It can be seen that the increase in current occurs when glucose is present, obtaining the current maximum between 3-3.6 $\mathrm{nA}$, which can be seen in the red areas. The reaction does not occur on the entire surface of the electrode, only in certain specific areas.

In the case of the enzyme alcohol dehydrogenase activity immobilized together with glucose oxidase, the evaluation was performed in a different way. It has been reported that hydrophilic $\left[\mathrm{Fe}_{3}(\mathrm{CN})_{6}\right]$ was employed as an extracellular electron acceptor and constituted a two-redox-mediator-based system together with lipophilic mediators. The two-redox-mediators-based system response originates from the reduction of a lipophilic mediator via nicotinamide adenine dinucleotide (NAD) [44, 45], which was used to localize ethanol oxidation using the enzyme ADH. The measurements were performed by applying a potential of $400 \mathrm{mV}$ in the UME using a substrate solution of $1 \mathrm{mM}$ potassium ferricyanide and $0.01 \mathrm{M}$ ethanol in a $0.1 \mathrm{M}$ phosphate buffer solution. Likewise, the current density increased in some areas of the analysed surface (red areas) in the presence of ethanol, indicating that the fuel oxidation process was carried out. In comparison with the distribution of the enzyme glucose oxidase, the enzyme alcohol dehydrogenase covers a larger area. The electrode has zones where the two enzymes are present and have negative effects because the protein structures of the enzymes block active sites inhibiting the enzymatic activity of the enzyme that is intercepted, therefore having no available sites to react with the density of current decrease.

\section{Performance of microfuel cell}

First, the device performance was carried using only glucose as a fuel; for this purpose, two different bioanodes were evaluated, one immobilized with glucose and one immobilized with ADH, the results are shown in Fig. 6a. In both cases, a solution of $0.01 \mathrm{M}$ glucose in a $0.1 \mathrm{M}$ buffer phosphate solution at $\mathrm{pH} 7$ was used as a fuel, and $0.3 \mathrm{M}$ $\mathrm{KOH}$ saturated-oxygen solution was used as oxidant for the cathodic compartment. It is observed that GOx bioanode alone produced a higher performance $(0.93 \pm 0.07 \mathrm{~V}$ of open circuit voltage $\mathrm{OCV}, 8.06 \pm 0.25 \mathrm{~mA} / \mathrm{cm}^{2}$ maximum current density $J_{\max }$ and $3.87 \mathrm{~mW} / \mathrm{cm}^{2} \pm 0.31$ maximum power density $P_{\max }$ compared with that obtained using a bi-enzyme electrode $\left(\mathrm{OCV}=0.9 \pm 0.1 \mathrm{~V}, J_{\max }=7.71 \pm 0.4 \mathrm{~mA} / \mathrm{cm}^{2}\right.$ and $P_{\max }=2.71 \pm 0.08 \mathrm{~mW} / \mathrm{cm}^{2}$ ). Similarly, the microfluidic device was evaluated using a solution of $0.01 \mathrm{M}$ ethanol in a phosphate buffer solution at $\mathrm{pH} 7$ and two different bioanodes (one with the enzyme ADH immobilized separately and a bi-enzymatic electrode). In this case, the performance of the cell using different anodes was similar, obtaining better results with the ADH electrode: $\mathrm{OCV}=1.02 \pm 0.11 \mathrm{~V}$, $J_{\max }=15.63 \pm 0.63 \mathrm{~mA} / \mathrm{cm}^{2}$ and $P_{\max }=4.95 \pm 0.45 \mathrm{~mW} / \mathrm{cm}^{2}$ as is shown in Fig. 6b. Comparing the bi-enzymatic anode performance gives a higher power density when using ethanol than when using glucose as a fuel due to the chemical nature of the fuel because it is easier to degrade ethanol than glucose $[39,46]$. The decrease in current density at the time when another enzyme is added at the electrode may be due to the increase in the protein mass, which is nonconductive or the enzyme is trapped, and its active sites are not available to react as can be observed in the scanning electrochemical microscopy studies. In the case of using a mixed solution of $0.01 \mathrm{M}$ glucose and $0.01 \mathrm{M}$ ethanol in a $0.1 \mathrm{M}$ buffer phosphate as a fuel, the microfluidic device was evaluated using the bi-enzymatic bioanode. Figure 7 a shows the obtained polarization curve $(\mathrm{OCV}=1.05 \pm 0.2 \mathrm{~V}$, $J_{\max }=16.15 \pm 1.2 \mathrm{~mA} / \mathrm{cm}^{2}$ and $P_{\max }=5.07 \pm 0.1 \mathrm{~mW} / \mathrm{cm}^{2}$ ). The flow rate used is $60 \mu \mathrm{L} / \mathrm{min}$ according to different flow rates tested in the microfluidic device (Fig. S3 in supplementary information). The fuel cell performance was compared with results of other enzymatic microfluidic fuel cell already reported, where the alcohol dehydrogenase and glucose oxidase were employed as biocatalyst (Table 1). The performance obtained with the bioanodes developed in this work showed a higher power density $\left(5071 \pm 100 \mu \mathrm{W} \mathrm{cm}{ }^{-2}\right)$. Actually being the first microfluidic fuel cell that uses a bienzymatic electrode (GOx and ADH) that has the ability to oxidize ethanol and glucose at the same time in the same device as far as we know.

A chronoamperometric measurement (Fig. 7b) was performed to determine the capability of supplying a constant current density over time using different solutions: $0.01 \mathrm{M}$ 
(a)

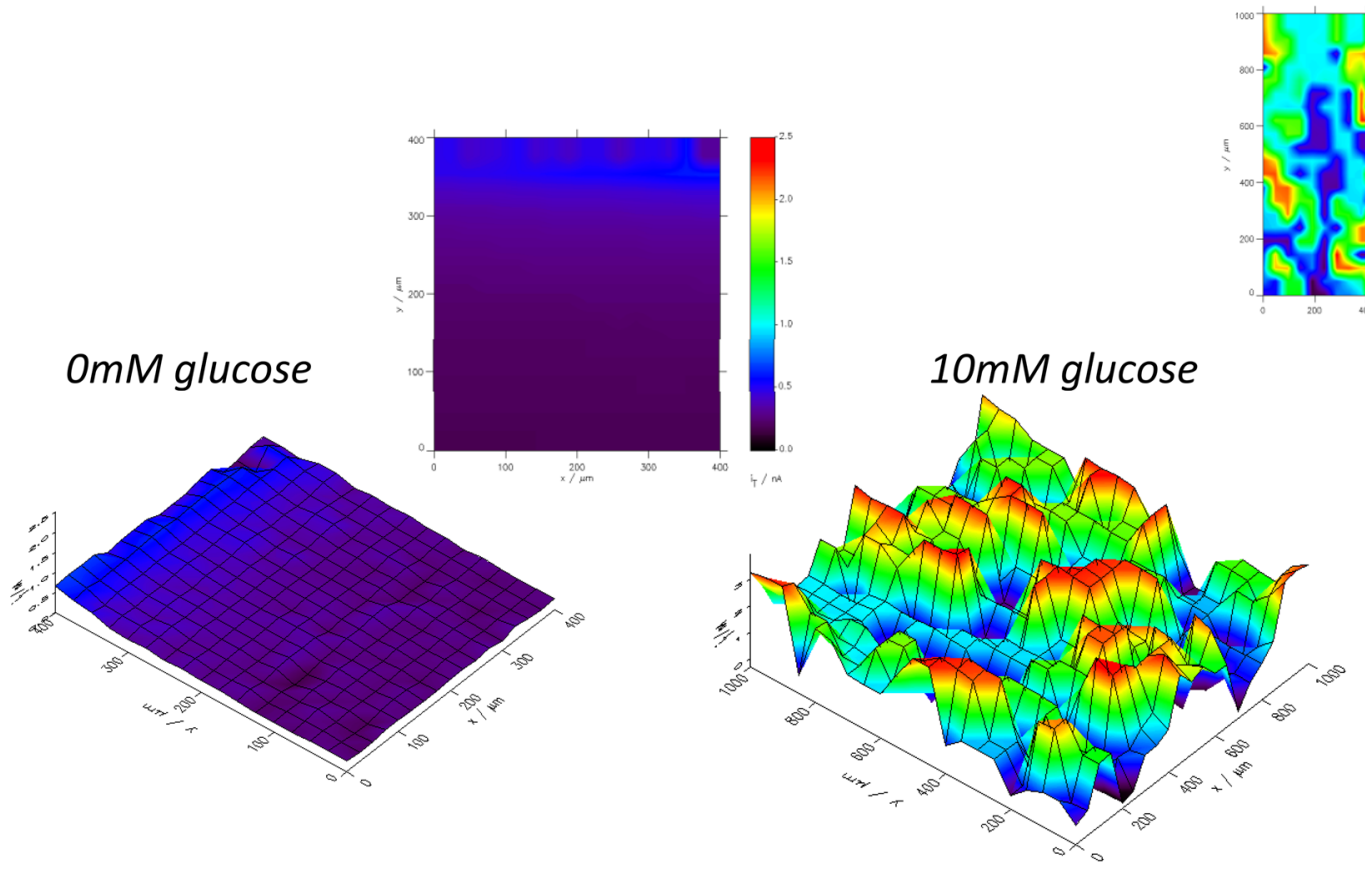

(b)

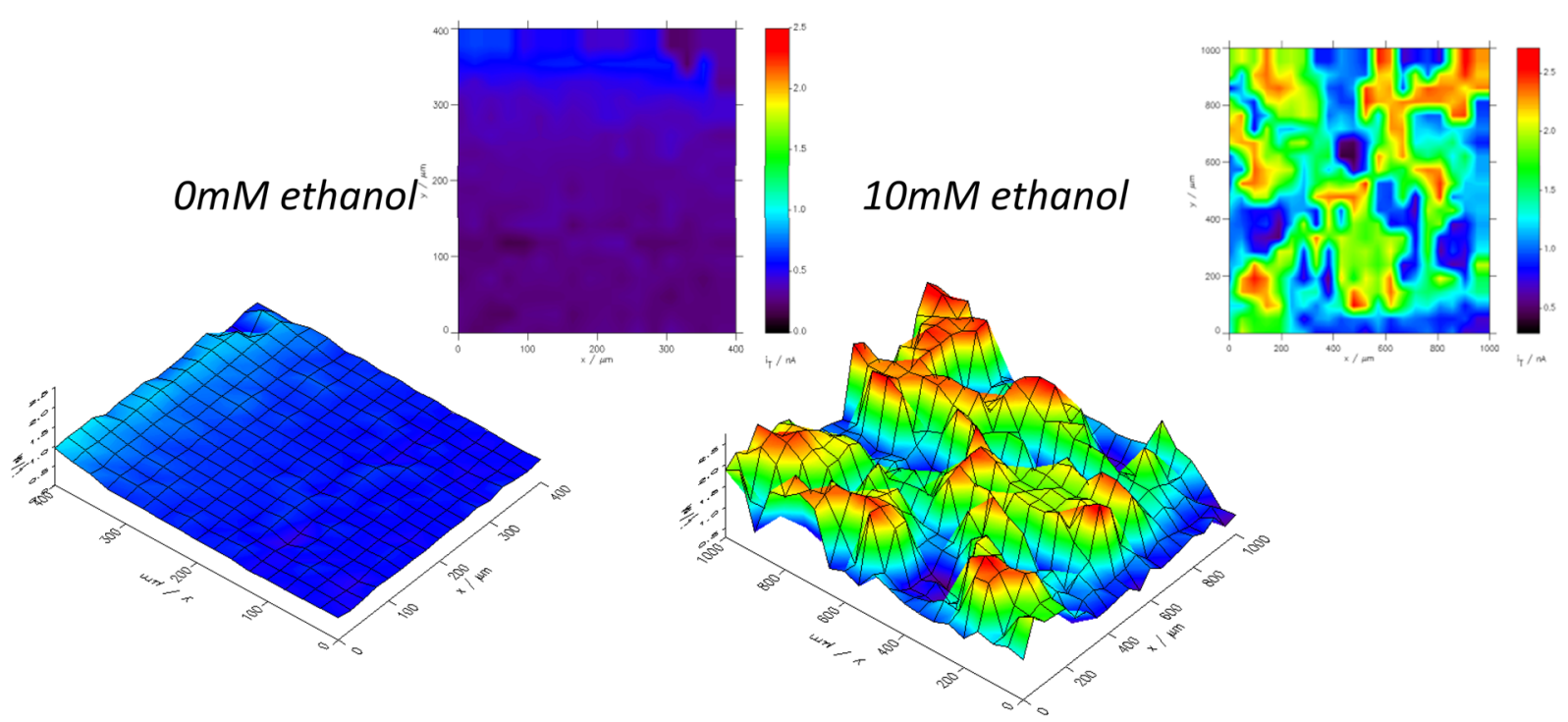

Fig. 5 Bi-enzymatic bioanode scanning electrochemical microscopy images. a Activity of glucose oxidase in the generator-collector SECM mode in the absence of glucose (left) and $10 \mathrm{mM}$ glucose (right) in $0.1 \mathrm{M}$ phosphate buffer $\mathrm{pH}=7, E_{\mathrm{t}}=0.7 \mathrm{~V}, d=53 \mu \mathrm{m}, 25 \mu \mathrm{m}$

glucose, $0.01 \mathrm{M}$ ethanol and $0.01 \mathrm{M}$ glucose with $0.01 \mathrm{M}$ ethanol, all in a $0.1 \mathrm{M}$ buffer phosphate solution at $\mathrm{pH} 7$. An increase in current density is observed in the mixture solution compared with the other two solutions, which is attributed to both reactions, ethanol and glucose oxidation, occurring at the same time on the bi-enzymatic electrode, which indicates that both enzymes are active on the electrode diameter Pt UME; and b Activity of alcohol dehydrogenase in the absence of ethanol (left) and $10 \mathrm{mM}$ ethanol (right) in $0.1 \mathrm{M}$ phosphate buffer $\mathrm{pH}=7, E_{\mathrm{t}}=0.4 \mathrm{~V}, d=53 \mu \mathrm{m}, 25 \mu \mathrm{m}$ diameter Pt UME

surface and can operate at the same time. A high stability during the evaluation period is also observed when different solutions were used. Figure S4, in supplementary information, shows the evaluation of the bi-enzymatic electrodes in the microfluidic device during 5 days of operation using the mixture of ethanol and glucose in phosphate buffer solution, where at the end of this test, there is a loss of $11.2 \%$ of power 

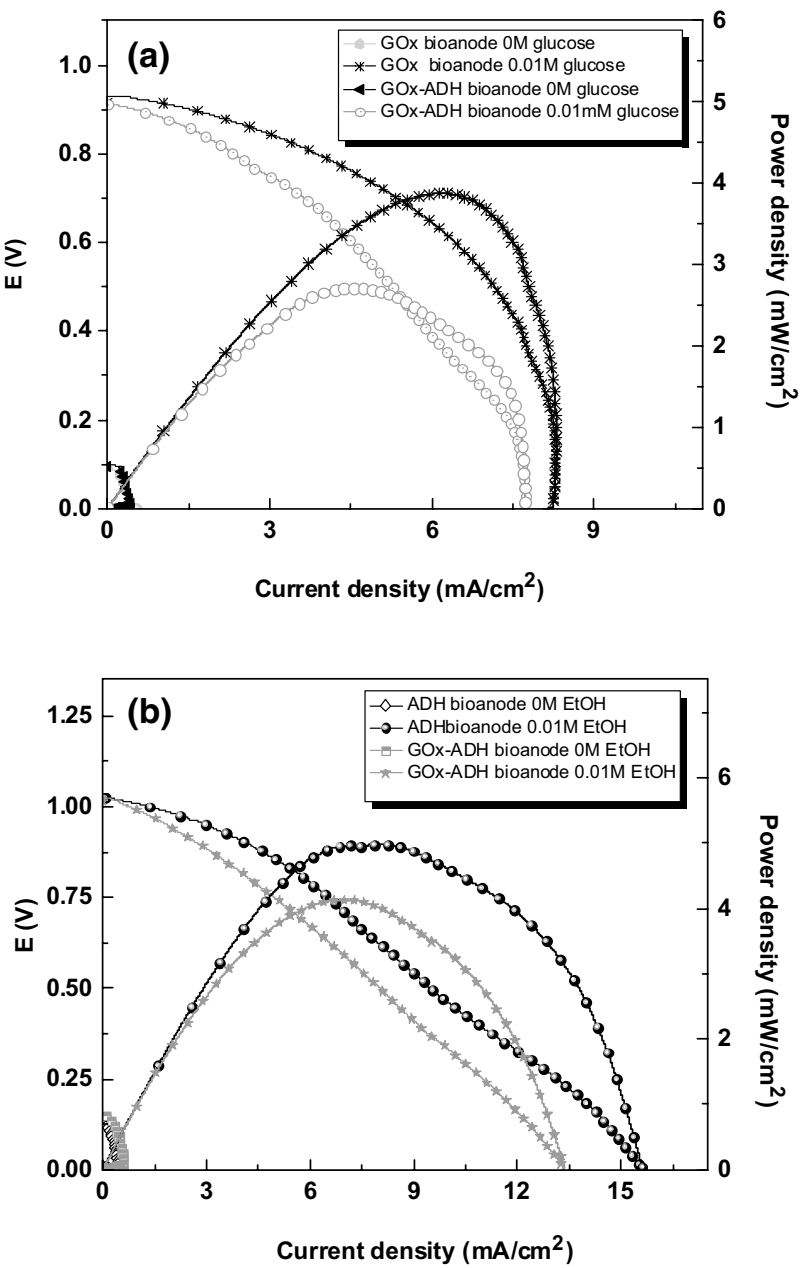

Fig. 6 a Polarisation and power density curves obtained from microfluidic fuel cell using two different bioanodes: glucose oxidase-based anode separately immobilized and mixed with alcohol dehydrogenase) in the absence and presence of glucose as fuel. b Polarisation and power density curves obtained from microfluidic fuel cell using two different bioanodes: alcohol dehydrogenase immobilized separately and mixed with glucose oxidase, in the absence and presence of ethanol as fuel in $0.1 \mathrm{M}$ phosphate buffer. Both at $\mathrm{pH} 7,25^{\circ} \mathrm{C}$ and $10 \mathrm{mV} \mathrm{s}^{-1}$.

density, indicating a good stability. Finally, the coulombic efficiency (CE) of the microfuel cell using the different fuels has been estimated by integration of the area under the current-time curve using the following Eq. 1 and 2 [47, 48]:

$\mathrm{CE}=\frac{C_{\mathrm{p}}}{C_{\mathrm{Ti}}} \times 100 \%$

$C_{\mathrm{Ti}}=\frac{F b_{i} S_{i} V}{M_{i}}$

where $C_{\mathrm{p}}$ is the total coulombs calculated by integrating the current over time from Fig. 7b. $C_{T i}$ is estimated according to Eq. 2, as the product of Faraday's constant $F, b_{i}$ is the
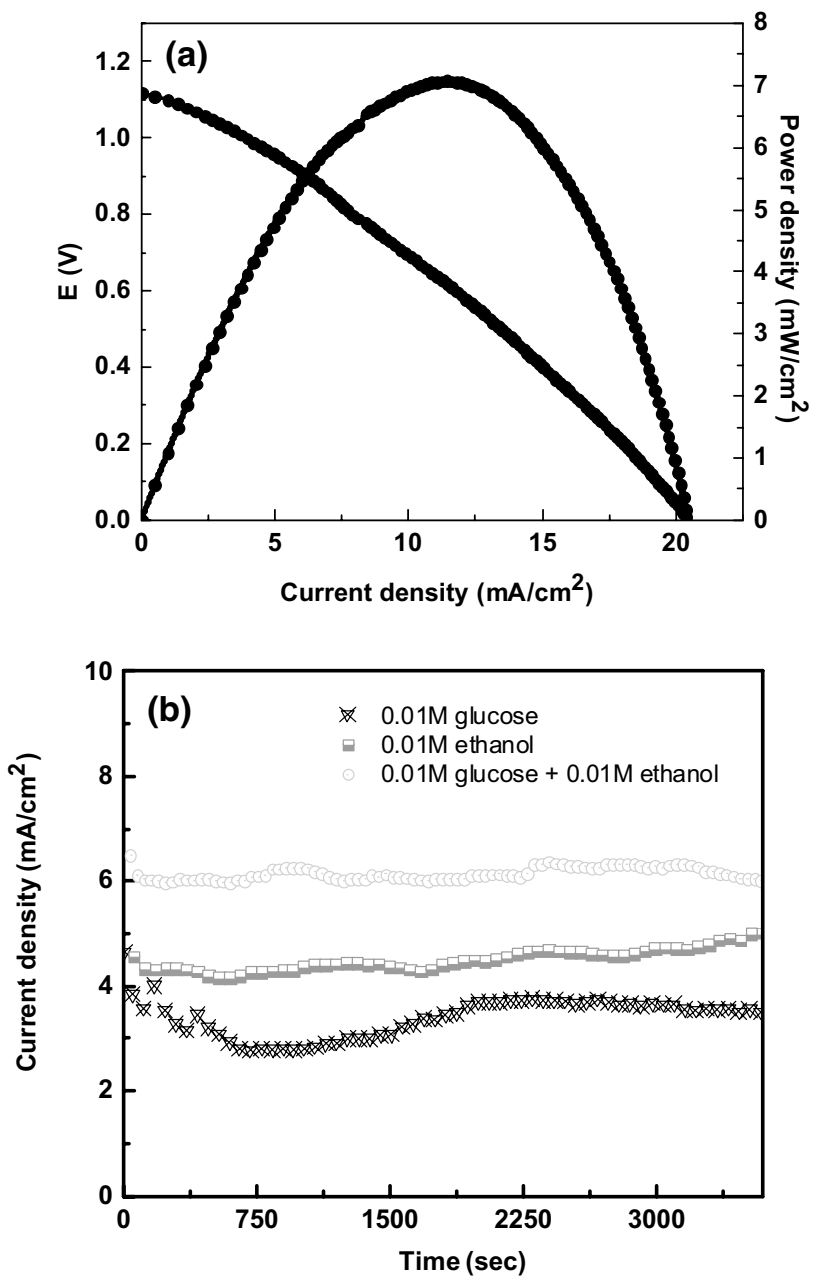

Fig. 7 a Polarisation and power density curve obtained from microfluidic fuel cell using a bi-enzymatic bioanode performance with a mixed solution composed of $0.01 \mathrm{M}$ glucose and $0.01 \mathrm{M}$ ethanol in $0.1 \mathrm{M}$ phosphate buffer $\mathrm{pH} 7,25^{\circ} \mathrm{C}$ at $10 \mathrm{mV} \mathrm{s}^{-1}$ and $0.3 \mathrm{M} \mathrm{KOH}$. b Chronoamperometry (at $0.02 \mathrm{~V}$ of potential) at the maximum current density obtained using bi-enzymatic bioanode in three different solutions as a fuel: $0.01 \mathrm{M}$ glucose, $0.1 \mathrm{M}$ ethanol and a mixed solution ( $0.01 \mathrm{M}$ glucose with 0.01 ethanol) in $0.1 \mathrm{M}$ phosphate buffer at $\mathrm{pH} 7$ and $0.3 \mathrm{M} \mathrm{KOH}$

number of moles of electrons produced per mole of the substrate, $S_{i}$ is the substrate concentration and $V$ is the volume of substrate used; the product is divided by $M_{i}$, molecular weight of the substrate. The CE values are $80 \%$ when glucose is used as fuel, $26.8 \%$ in the presence of ethanol and $44.8 \%$ with glucose/ethanol mixture.

\section{Performance of the microfuel cell using alcoholic beverage as a fuel}

To show the versatility and high activity of the bioelectrode, different alcoholic beverages were used as fuel as a first attempt at real concept application, which is listed 
Table 1 Comparison of microfluidic fuel cells performance, already reported, that employ alcohol dehydrogenase and glucose oxidase enzymes as bioanodes

\begin{tabular}{|c|c|c|c|c|}
\hline Anode (anolyte) & Cathode (catholyte) & $\mathrm{OCV}(\mathrm{V})$ & $\mu \mathrm{Wcm}^{-2}$ & Reference \\
\hline \multicolumn{5}{|l|}{ Microfluidic fuel cell with glucose oxidase as bioanode } \\
\hline $\begin{array}{l}(\mathrm{GOx} / \mathrm{VC}-\mathrm{MWCNT}-\mathrm{GA})(5 \mathrm{mM} \text { glucose in buffer } \\
\text { phosphate }=7.4)\end{array}$ & Pt 20\% E-Tek carbon ( $\mathrm{KOH} 0.3 \mathrm{M}$ saturated with $\mathrm{O}_{2}$ ) & 0.52 & 2000 & [36] \\
\hline \multicolumn{5}{|l|}{ Microfluidic fuel cell with alcohol dehydrogenase as bioanode } \\
\hline $\begin{array}{l}\text { Toray carbon paper/ADH }+ \text { AldH/ + poly-MB/ TBAB/ } \\
\mathrm{NAD}^{+} \\
(0.1 \mathrm{M} \text { EtOH in buffer phosphate } \mathrm{pH}=8.86)\end{array}$ & Pt $20 \%$ E-Tek carbon $\left(\mathrm{KOH} 0.3 \mathrm{M}\right.$ saturated with $\mathrm{O}_{2}$ ) & 1.14 & 1600 & [39] \\
\hline $\begin{array}{l}\mathrm{ADH} / \text { carbon } \mathrm{KS} 6+\mathrm{NAD}^{+} / \mathrm{VK} 3 / \text { acetone/PEI } \\
(\mathrm{EtOH} 160 \mu \mathrm{L} \text { in } \mathrm{PBS} \mathrm{pH} 9)\end{array}$ & $\begin{array}{l}\text { Laccase }+ \text { ABTS }+ \text { Super } P ®+\text { Nafion }(\text { PBS at pH } 5 \\
\text { saturated with } \mathrm{O}_{2} \text { ) }\end{array}$ & 0.6 & 90 & [46] \\
\hline $\begin{array}{l}\text { Toray paper carbon/poly-MB/Nafion + glutaralde- } \\
\text { hyde/ADH / NAD }{ }^{+} \text {(EtOH } 1 \mathrm{~g} / \mathrm{L} \text { in buffer phosphate } \\
\mathrm{pH}=7.4)\end{array}$ & Pt 20\% E-Tek carbon ( $\mathrm{KOH} 0.3 \mathrm{M}$ saturated with $\mathrm{O}_{2}$ ) & 1.035 & 3154 & {$[34]$} \\
\hline \multicolumn{5}{|c|}{ Microfluidic fuel cell with alcohol dehydrogenase and glucose oxidase as bioanode } \\
\hline $\begin{array}{l}\text { Toray paper carbon/funcionalizated carbon nanofib- } \\
\text { ers/Nafion/ADH/GOx }(10 \mathrm{mM} \mathrm{EtOH}+10 \mathrm{mM} \\
\text { glucose in buffer phosphate } \mathrm{pH}=7)\end{array}$ & Pt 20\% E-Tek carbon ( $\mathrm{KOH} 0.3 \mathrm{M}$ saturated with $\mathrm{O}_{2}$ ) & 1.05 & 5071 & This work \\
\hline
\end{tabular}

$T B A B$ tetrabutylammonium bromide; $P E I$ polyethylenimine; poly- $M G$ poly-methylene green; $M W C T_{S}$ carbon nanotubes; $Q H$ quino-haemoprotein; VK3 2-methyl-1,4-naphthoquinone; $A B T S$ diammonium salt; poly-MB poly-methylene blue; $G A$ glutaraldehyde

Table 2 Alcohol and glucose content of alcoholic beverages used as fuel in the microfluidic fuel cell

\begin{tabular}{lll}
\hline Fuel & $\begin{array}{l}\text { Alcohol con- } \\
\text { centration (\%) }\end{array}$ & $\begin{array}{l}\text { Sugar } \\
\text { content } \\
(\%)\end{array}$ \\
\hline Tequila & 37 & 0 \\
Pink Tequila & 35 & 0.5 \\
Cider & 4.5 & 9 \\
Rose wine & 11 & 22 \\
Red wine & 11 & 1 \\
White wine & 11 & 1.9 \\
Brandy & 38 & 1.9 \\
Vodka & 40 & 0 \\
Alcohol beverage mango flavour & 4.7 & 19 \\
Alcohol beverage cherry, raspberry and & 13 & 19 \\
$\quad$ blackberry flavour & & 18 \\
Alcohol beverage pina colada flavour & 4 & \\
\hline
\end{tabular}

in Table 2. This table also shows the alcohol and glucose content (alcohol content was obtained from the legend presented on each container of the alcoholic beverages). Figure 8a shows the polarization and power density curves, and in Fig. 8b, it is possible to see more clearly the power density generated by each of the different alcoholic beverages. The beverage fuel that produced the highest power density was brandy $\left(4.36 \pm 0.09 \mathrm{~mW} / \mathrm{cm}^{2}\right)$, compared with vodka, whose alcohol content is the highest at $40 \%$. Two types of tequilas were used, white tequila (more common) and pink tequila (Mexican tequila elaborated with infusions of jamaica to give the pink colour and caramel to give a sweet flavour).
Pink tequila yielded a higher power density of $3.96 \pm 0.16$ $\mathrm{mW} / \mathrm{cm}^{2}$ compared with common tequila $(3.37 \pm 0.073 \mathrm{~mW} /$ $\mathrm{cm}^{2}$ ), where the principal difference in both is the sugar present in Pink tequila, which is advantageous to increasing the glucose oxidation reaction by the enzyme glucose oxidase. Different commercial cocktails were also used as fuels, which contain a glucose concentration. However, two of them (pina colada and mango flavours) yielded the lowest power densities. These results coincide with the low alcohol content according to Table 2. The bioanode has better performance in the presence of alcohol than glucose due to the chemical nature of the fuel because it is easier to degrade ethanol than glucose. All alcoholic beverages were used at high acidic $\mathrm{pH}$ (3.1-3.7). Thus, the cell power was not very high compared with phosphate buffer solutions at $\mathrm{pH}$ 7. The only alcoholic drink with $\mathrm{pH} 7.2$ was the cocktail of cherry-raspberry-blackberry flavour, which exhibited good performance due to its content of sugars and alcohol $\left(2.7 \pm 0.081 \mathrm{~mW} / \mathrm{cm}^{2}\right)$. A prospective use of the bi-enzymatic electrode incorporated in a Lab-on-a-Chip or flexible epidermal devices [49], where it can use different alcoholic beverages at different alcohol and glucose concentrations, presents alternative applications (detectors, quality and alcoholic content) for the alcoholic drinks industry.

\section{Conclusions}

Using the proposed immobilization method, two enzymes of a different nature can be confined to the same electrode, glucose oxidase being FAD-dependent and alcohol 
(a)

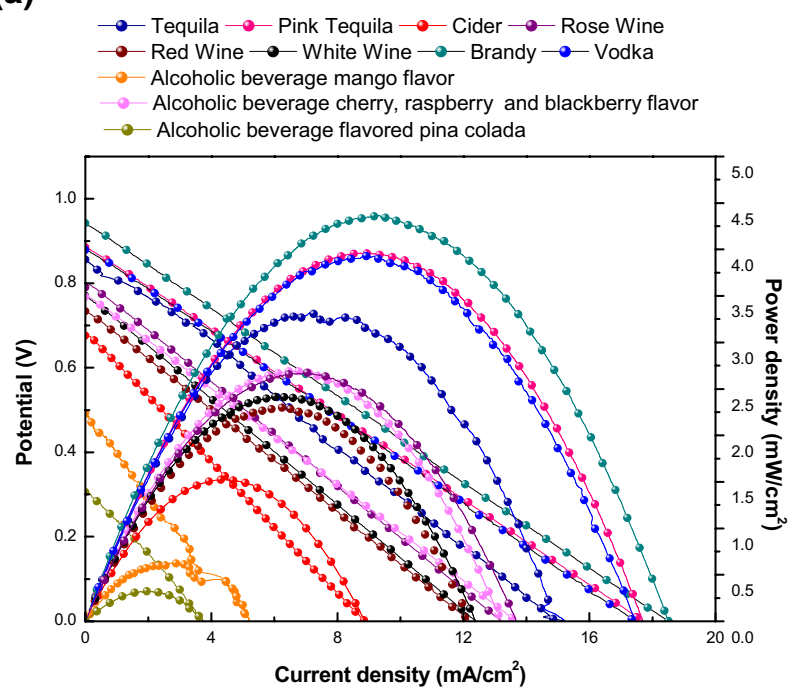

(b)

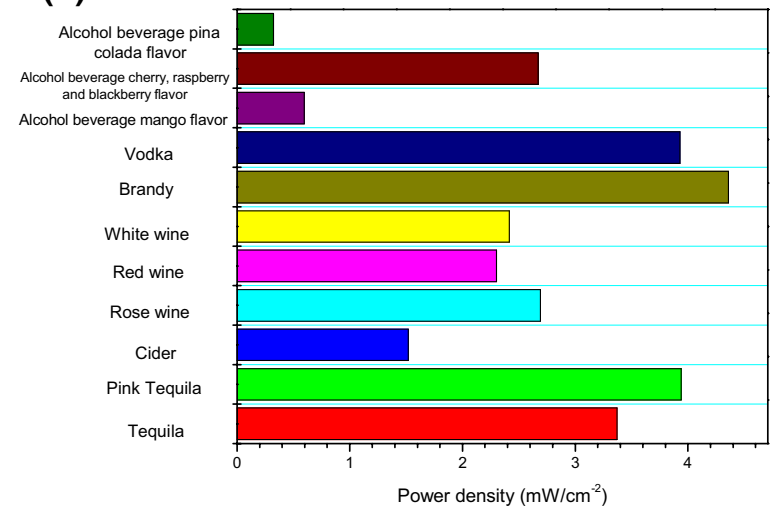

Fig. 8 a Polarisation and power density curves obtained from the microfluidic fuel cell using different alcoholic beverage as fuels and bi-enzymatic bioanode in $0.3 \mathrm{M} \mathrm{KOH}$. b Bar graph indicating the power generated by the microfluidic cell using different alcoholic beverages

dehydrogenase being NAD-dependent. Using different techniques, it was possible to demonstrate that enzymes remain active and are selective, finding the optimum parameters of $\mathrm{pH}$ and temperature for each one, and obtaining using a neutral $\mathrm{pH}$, where the enzymes do not present an appreciable loss of catalytic activities. It was possible to observe the selectivity toward oxidation reactions of each enzyme to the corresponding substrate by scanning electrochemical microscope technique. Using the obtained images, there is no significant overlap between GOx and ADH. By evaluating the microfluidic cell using different solutions, such as glucose, ethanol and the mixture of them, it was possible to determine that there was an increase in the current density when ethanol and glucose were used at the same time. The objective of testing different alcoholic beverages as a fuel in the evaluation of microfluidic cell demonstrates the versatility of the bi-enzymatic anode, obtaining significant performance even when the $\mathrm{pH}$ of these drinks is acidic, showing a possible integration of the bioelectrode developed in a Lab-on-a-Chip system.

Supplementary Information The online version contains supplementary material available at https://doi.org/10.1007/s40243-022-00207-2.

Acknowledgements The authors acknowledge the Mexican Council for Science and Technology (CONACYT) for the financial support through the project Ciencia de Frontera grant No. 845132; also thanks to J. Galindo-de-la-Rosa for him support in some characterization techniques.

Open Access This article is licensed under a Creative Commons Attribution 4.0 International License, which permits use, sharing, adaptation, distribution and reproduction in any medium or format, as long as you give appropriate credit to the original author(s) and the source, provide a link to the Creative Commons licence, and indicate if changes were made. The images or other third party material in this article are included in the article's Creative Commons licence, unless indicated otherwise in a credit line to the material. If material is not included in the article's Creative Commons licence and your intended use is not permitted by statutory regulation or exceeds the permitted use, you will need to obtain permission directly from the copyright holder. To view a copy of this licence, visit http://creativecommons.org/licenses/by/4.0/.

\section{References}

1. Sakuta, R., Takeda, K., Ishida, T., Igarashi, K., Samejima, M., Nakamura, N., Ohno, H.: Multi-enzyme anode composed of FADdependent and NAD-dependent enzymes with a single ruthenium polymer mediator for biofuel cells. Electrochem. Commun. 56, 75-78 (2015). https://doi.org/10.1016/j.elecom.2015.04.013

2. Shao, M., Nadeem, M., Sygmund, C., Guschin, D.A., Ludwig, R., Peterbauer, C.K., Schuhmann, W., Gorton, L.: Mutual enhancement of the current density and the coulombic efficiency for a bioanode by entrapping bi-enzymes with Os-complex modified electrodeposition paints. Biosens. Bioelectron. 40, 308-314 (2013). https://doi.org/10.1016/j.bios.2012.07.069

3. Nguyen, H.H., Lee, S.H., Lee, U.J., Fermin, C.D., Kim, M.: Immobilized enzymes in biosensor applications. Materials 12, 121 (2019). https://doi.org/10.3390/ma12010121

4. Ramanavicius, A., Kausaite, A., Ramanaviciene, A.: Enzymatic biofuel cell based on anode and cathode powered by ethanol. Biosens. Bioelectron. 24, 761-766 (2008). https://doi.org/10.1016/j. bios.2008.06.048

5. Wala, M., Simka, W.: Effect of anode material on electrochemical oxidation of low molecular weight alcohols - a review (2021)

6. Escalona-Villalpando, R.A., Sandoval-García, A., Espinosa, L., Miranda-Silva, M.G., Arriaga, L.G., Minteer, S.D., LedesmaGarcía, J.: A self-powered glucose biosensor device based on microfluidics using human blood. J. Power Sources. 515, 230631 (2021). https://doi.org/10.1016/j.jpowsour.2021.230631

7. Kundu, A., Jang, J.H., Gil, J.H., Jung, C.R., Lee, H.R., Kim, S., $\mathrm{Ku}, \mathrm{B}$., Oh, Y.S.: Micro-fuel cells-current development and applications. J. Power Sources 170, 67-78 (2007). https://doi. org/10.1016/j.jpowsour.2007.03.066

8. Kjeang, E., Sinton, D., Harrington, D.A.: Strategic enzyme patterning for microfluidic biofuel cells. J. Power Sources. 158, 1-12 (2006). https://doi.org/10.1016/j.jpowsour.2005.07.092 
9. Wang, X., Wang, J., Sun, X., Wei, S., Cui, L., Yang, W., Liu, J.: Hierarchical coral-like NiMoS nanohybrids as highly efficient bifunctional electrocatalysts for overall urea electrolysis. Nano Res. 11, 988-996 (2018). https://doi.org/10.1007/ s12274-017-1711-3

10. Desmaële, D., Nguyen-Boisse, T.T., Renaud, L., Tingry, S.: A novel ethanol/oxygen microfluidic fuel cell with enzymes immobilized onto cantilevered porous electrodes. J. Phys. Conf. Ser. 773, 12016 (2016)

11. Reid, R.C., Jones, S.R., Hickey, D.P., Minteer, S.D., Gale, B.K.: Modeling carbon nanotube connectivity and surface activity in a contact lens biofuel cell. Electrochim. Acta. 203, 30-40 (2020). https://doi.org/10.1016/j.electacta.2016.04.012

12. Scherbahn, V., Putze, M.T., Dietzel, B., Heinlein, T., Schneider, J.J., Lisdat, F.: Biofuel cells based on direct enzyme-electrode contacts using PQQ-dependent glucose dehydrogenase/bilirubin oxidase and modified carbon nanotube materials. Biosens. Bioelectron. 61, 631-638 (2014). https://doi.org/10.1016/j.bios. 2014.05.027

13. Escalona-Villalpando, R.A., Ortiz-Ortega, E., BocanegraUgalde, J.P., Minteer, S.D., Ledesma-García, J., Arriaga, L.G.: Clean energy from human sweat using an enzymatic patch. J. Power Sources. 412, 496-504 (2019). https://doi.org/10.1016/j. jpowsour.2018.11.076

14. Cirillo, G., Nicoletta, F.P., Curcio, M., Spizzirri, U.G., Picci, N., Iemma, F.: Enzyme immobilization on smart polymers: catalysis on demand. React. Funct. Polym. 83, 62-69 (2014). https:// doi.org/10.1016/j.reactfunctpolym.2014.07.010

15. Filip, J., Tkac, J.: Is graphene worth using in biofuel cells? Electrochim. Acta 136, 340-354 (2014). https://doi.org/10.1016/j. electacta.2014.05.119

16. Sassolas, A., Blum, L.J., Leca-bouvier, B.D.: Immobilization strategies to develop enzymatic biosensors. Biotechnol. Adv. 30, 489-511 (2012). https://doi.org/10.1016/j.biotechadv.2011.09. 003

17. Soukharev, V., Mano, N., Heller, A.: A four-electron $\mathrm{O}_{2}$-electroreduction biocatalyst superior to platinum and a biofuel cell operating at 0.88 V. J. Am. Chem. Soc. 126, 8368-8369 (2004). https://doi.org/10.1021/ja0475510

18. Calabrese Barton, S., Gallaway, J., Atanassov, P.: Enzymatic biofuel cells for implantable and microscale devices. Chem. Rev. 104, 4867-4886 (2004). https://doi.org/10.1021/cr020719k

19. Szczupak, A., Halámek, J., Halámková, L., Bocharova, V., Alfonta, L., Katz, E.: Living battery-biofuel cells operating in vivo in clams. Energy Environ. Sci. 5, 8891-8895 (2012). https://doi.org/10.1039/C2EE21626D

20. De Poulpiquet, A., Ciaccafava, A., Lojou, E.: New trends in enzyme immobilization at nanostructured interfaces for efficient electrocatalysis in biofuel cells. Electrochim. Acta 126, 104-114 (2014). https://doi.org/10.1016/j.electacta.2013.07.133

21. Liu, J., Zhang, X., Pang, H., Liu, B., Zou, Q., Chen, J.: High-performance bioanode based on the composite of CNTs-immobilized mediator and silk film-immobilized glucose oxidase for glucose/ $\mathrm{O}_{2}$ biofuel cells. Biosens. Bioelectron. 31, 170-175 (2012). https://doi.org/10.1016/j.bios.2011.10.011

22. Yu, C.M., Yen, M.J., Chen, L.C.: A bioanode based on MWCNT/ protein-assisted co-immobilization of glucose oxidase and 2,5-dihydroxybenzaldehyde for glucose fuel cells. Biosens. Bioelectron. 25, 2515-2521 (2010). https://doi.org/10.1016/j.bios. 2010.04.016

23. Mazar, F.M., Alijanianzadeh, M., Molaeirad, A., Heydari, P.: Development of novel glucose oxidase immobilization on graphene/gold nanoparticles/poly neutral red modified electrode. Process Biochem. 56, 71-80 (2017). https://doi.org/10.1016/j. procbio.2017.02.008
24. Kirthiga, M., Rajendran, L., Fernandez, C.: Theoretical treatment of diffusion and kinetics of osmium redox polymer mediated glucose oxidase enzyme electrodes: analytical expression of current density for varying potential. Electrochim. Acta (2017). https:// doi.org/10.1016/j.electacta.2017.01.149

25. Idris, S., Ahmad, A.A., Thevy Ratnam, C., Kamaruddin, N.H., Shaari, S.: Influence of gamma irradiation on polymerization of pyrrole and glucose oxidase immobilization onto poly (pyrrole)/ poly (vinyl alcohol) matrix. Appl. Surf. Sci. 400, 118-128 (2017). https://doi.org/10.1016/j.apsusc.2016.12.175

26. Zhang, F., Wu, X., Gao, J., Chen, Y., Gui, Y., Zhang, L., Gan, W., Yuan, Q.: Fabrications of metal organic frameworks derived hierarchical porous carbon on carbon nanotubes as efficient bioanode catalysts of NAD+-dependent alcohol dehydrogenase. Electrochim. Acta 340, 135958 (2020). https://doi.org/10.1016/j.elect acta.2020.135958

27. Gao, F., Jiang, Y., Hu, M., Li, S., Zhai, Q.: Bienzymatic nanoreactors composed of chloroperoxidase-glucose oxidase on Au@ $\mathrm{Fe}_{3} \mathrm{O}_{4}$ nanoparticles: dependence of catalytic performance on the bioarchitecture. JMADE. 111, 414-420 (2016). https://doi.org/10. 1016/j.matdes.2016.09.025

28. Sapountzi, E., Braiek, M., Vocanson, F., Chateaux, J.F., JaffrezicRenault, N., Lagarde, F.: Gold nanoparticles assembly on electrospun poly(vinyl alcohol)/poly(ethyleneimine)/glucose oxidase nanofibers for ultrasensitive electrochemical glucose biosensing. Sens. Actuators B Chem. 238, 392-401 (2017). https://doi.org/10. 1016/j.snb.2016.07.062

29. Zhou, M., Deng, L., Wen, D., Shang, L., Jin, L., Dong, S.: Highly ordered mesoporous carbons-based glucose $/ \mathrm{O}_{2}$ biofuel cell. Biosensors Bioelectron. 24, 2904-2908 (2009). https://doi.org/10. 1016/j.bios.2009.02.028

30. Zebda, A., Gondran, C., Cinquin, P., Cosnier, S.: Glucose biofuel cell construction based on enzyme, graphite particle and redox mediator compression. Sens. Actuators B Chem. 173, 760-764 (2012). https://doi.org/10.1016/j.snb.2012.07.089

31. Alam, M.F., Laskar, A.A., Zubair, M., Baig, U., Younus, H.: Immobilization of yeast alcohol dehydrogenase on polyaniline coated silver nanoparticles formed by green synthesis. J. Mol. Catal. B Enzym. 119, 78-84 (2015). https://doi.org/10.1016/j. molcatb.2015.06.004

32. Álvarez, L., Acevedo, F., Illanes, A.: Induction of NAD+ dependent alcohol dehydrogenases with activity towards long chain aliphatic alcohols in mesophilic, thermophilic and extreme thermophilic microorganisms. Process Biochem 46, 1342-1349 (2011). https://doi.org/10.1016/j.procbio.2011.03.002

33. Bilgi, M., Ayranci, E.: Biosensor application of screen-printed carbon electrodes modified with nanomaterials and a conducting polymer: ethanol biosensors based on alcohol dehydrogenase. Sens. Actuators B Chem. 237, 849-855 (2016). https://doi.org/10. 1016/j.snb.2016.06.164

34. Wu, L., Zhang, X., Ju, H.: Amperometric glucose sensor based on catalytic reduction of dissolved oxygen at soluble carbon nanofiber. Biosensors Bioelectron. 23, 479-484 (2007). https:// doi.org/10.1016/j.bios.2007.06.009

35. Dector, A., Escalona-Villalpando, R.A., Dector, D., Vallejobecerra, V.: Perspective use of direct human blood as an energy source in air- breathing hybrid micro fluidic fuel cells. J. Power Sources 288, 70-75 (2015). https://doi.org/10.1016/j.jpowsour. 2015.04.089

36. Tian, J., Liu, Q., Asiri, A.M., Qusti, A.H., Al-Youbi, A.O., Sun, $\mathrm{X}$.: Ultrathin graphitic carbon nitride nanosheets: a novel peroxidase mimetic, Fe doping-mediated catalytic performance enhancement and application to rapid, highly sensitive optical detection of glucose. Nanoscale 5, 11604-11609 (2013). https://doi.org/10. 1039/C3NR03693F 
37. Fernández-Fernández, M., Sanromán, M.Á., Moldes, D.: Recent developments and applications of immobilized laccase. Biotechnol. Adv. 31, 1808-1825 (2013). https://doi.org/10.1016/j.biote chadv.2012.02.013

38. Akers, N.L., Moore, C.M., Minteer, S.D.: Development of alcohol $/ \mathrm{O}_{2}$ biofuel cells using salt-extracted tetrabutylammonium bromide/nafion membranes to immobilize dehydrogenase enzymes. Electrochim. Acta 50, 2521-2525 (2005). https://doi.org/10. 1016/j.electacta.2004.10.080

39. Xu, S., Minteer, S.D.: Enzymatic biofuel cell for oxidation of glucose to $\mathrm{CO}_{2}$. ACS Catal. 2, 91-94 (2012). https://doi.org/10. $1021 / \mathrm{cs} 200523 \mathrm{~s}$

40. Daniel, R.M., Danson, M.J.: Temperature and the catalytic activity of enzymes: a fresh understanding. FEBS Lett. (2013). https://doi. org/10.1016/j.febslet.2013.06.027

41. Burchardt, M., Wittstock, G.: Kinetic studies of glucose oxidase in polyelectrolyte multilayer films by means of scanning electrochemical microscopy (SECM). Bioelectrochemistry 72, 66-76 (2008). https://doi.org/10.1016/j.bioelechem.2007.11.010

42. Schäfer, D., Maciejewska, M., Schuhmann, W.: SECM visualization of spatial variability of enzyme-polymer spots. 1. Discretisation and interference elimination using artificial neural networks. Biosens. Bioelectron. 22, 1887-1895 (2007). https://doi.org/10. 1016/j.bios.2006.07.039

43. Morkvenaite-Vilkonciene, I., Ramanaviciene, A., Ramanavicius, A.: Redox competition and generation-collection modes based scanning electrochemical microscopy for the evaluation of immobilised glucose oxidase-catalysed reactions. RSC Adv. 4, 50064 50069 (2014). https://doi.org/10.1039/C4RA08697J

44. Morkvenaite-Vilkonciene, I., et al.: 9,10-Phenanthrenequinone as a redox mediator for the imaging of yeast cells by scanning electrochemical microscopy. Sens Actuators B. Chem. 228, 200206 (2016). https://doi.org/10.1016/j.snb.2015.12.102

45. Zhao, J., Wang, M., Yang, Z., Wang, Z., Wang, H., Yang, Z.: The different behaviors of three oxidative mediators in probing the redox activities of the yeast Saccharomyces cerevisiae. Anal. Chim. Acta 597, 67-74 (2007). https://doi.org/10.1016/j.aca.2007. 06.023

46. Selloum, D., Tingry, S., Techer, V., Renaud, L., Innocent, C., Zouaoui, A.: Optimized electrode arrangement and activation of bioelectrodes activity by carbon nanoparticles for efficient ethanol microfluidic biofuel cells. J. Power Sources 269, 834-840 (2014). https://doi.org/10.1016/j.jpowsour.2014.07.052

47. Anwer, A.H., Khan, N., Khan, M.D., Shakeel, S., Khan, M.Z.: Redox mediators as cathode catalyst to boost the microbial electro-synthesis of biofuel product from carbon dioxide. Fuel 302, 121124 (2021). https://doi.org/10.1016/j.fuel.2021.121124

48. Das, P., Bachu, V., Barbora, L., Dutta, A., Sarma, M.K., Goswami, P.: Passive fuel delivery and efficient anoxic condition in anode improve performance of methanol biofuel cell. Appl. Energy 305, 117824 (2022). https://doi.org/10.1016/j.apenergy.2021.117824

49. Sun, M., Gu, Y., Pei, X., Wang, J., Liu, J., Ma, C., Bai, J., Zhou, M.: A flexible and wearable epidermal ethanol biofuel cell for on-body and real-time bioenergy harvesting from human sweat. Nano Energy 86, 106061 (2021). https://doi.org/10.1016/j.nanoen. 2021.106061

Publisher's Note Springer Nature remains neutral with regard to jurisdictional claims in published maps and institutional affiliations. 